Yüzüncü Yil Üniversitesi
Tarim Bilimleri Dergisi

Araştırma Makalesi (Research Article)

\title{
Bazı Pestisit Uygulamalarından Sonra Toprakta Hedef Olmayan Nematod, Bakteri ve Mikrofungus Popülasyonlarının Değişimi* ${ }^{* *}$
}

\author{
Ayşenur GÜVEN*1, İbrahim KOÇ ${ }^{2}$ \\ ${ }^{1}$ Bitlis Eren Üniversitesi, Fen Bilimleri Enstitüsü, Çevre Mühendisliği ABD, 13000, Bitlis, Türkiye \\ ${ }^{2}$ Bitlis Eren Üniversitesi, Mühendislik-Mimarlık Fakültesi, Çevre Mühendisliği Bölümü, 13000, Bitlis, Türkiye \\ 1https://orcid.org/0000-0002-0976-7545 ²https://orcid.org/0000-0003-0803-6801 \\ *Sorumlu yazar e-posta: aysenur.guven13@gmail.com
}

\section{Makale Bilgileri}

Geliş: 14.02 .2020

Kabul: 11.05 .2020

Online Yayınlanma 30.06.2020

DOI: $10.29133 /$ yyutbd.689385

\section{Anahtar kelimeler}

Bakteri,

Bitlis,

Mikrofungus,

Pestisitler,

Toprak,

Nematod.
Öz: Tarımsal alanlar, insan müdahalesi ile kimyasal girdilerin olduğu önemli ekolojik ortamlardır. Bu ortamların varlığı, insanlar için önemli olduğu kadar ortamı paylaşan diğer canlılar için de önemlidir. Bu araştırma, Bitlis İli tarımsal alanlarında yaygın kullanılan Satellite $20 \mathrm{WP}$, Status 330 E, Pesos 100 EC ve Pentran 22 E pestisitlerinin hedef olmayan topraktaki nematod, aerobik mezofilik bakteri, mikrofungus popülasyonları ve toprak $\mathrm{pH}$ 'sına etkilerini belirlemek amacıyla yapılmıştır. Çalışma, in-vitro şartlarında tekrarlı ölçümlerde varyans analizi yöntemine göre altı tekerrürlü olarak yürütülmüştür. Yapılan varyans analizlerine göre Periyot $\times$ Uygulama interaksiyonlarının sirasıyla $\mathrm{pH}$, bitki paraziti ve fungivor nematodlar için önemli olduğu $(\mathrm{P}=0.007 ; \mathrm{P}=0.008 ; \mathrm{P}=0.000)$, omnivoravc1, bakterivor ve toplam nematodlar için hem periyot $(\mathrm{P}=0.000 ; \mathrm{P}=0.000$; $\mathrm{P}=0.000$ ) hem de pestisit uygulamalarının ana etkisinin istatistiksel olarak önemli olduğu ( $\mathrm{P}=0.046 ; \mathrm{P}=0.017 ; \mathrm{P}=0.009$ ) bulunmuştur. Profil analizlerine göre; $\mathrm{pH}$ 'ın, özellikle Satellite 20 WP uygulamasında artış gösterdiği aerobik mezofilik bakteri sayısının, kontrolde artmasına karşın tüm pestisit uygulamalarında azalma gösterdiği; mikrofungus sayısının, Pesos $100 \mathrm{EC}$ uygulamasında artış göstermesine karşın diğer uygulamalarda azaldığı; bitki paraziti, fungivor ve toplam nematod sayılarının tüm pestisit uygulamalarında azaldığı; omnivor-avcı ve bakterivor nematodların kısmen etkilendiği görülmüştür. Sonuç olarak; kullanılan pestisitlerin, dikkate alınan parametrelere göre olumlu ya da olumsuz etkisinin olduğu belirlenmiştir.

\section{Diversity of Non-Targeted Nematode, Bacteria and Microfungi Populations in Soil After Some Pesticide Treatment}

\section{Article Info}

Received: 14.02 .2020

Accepted: 11.05.2020

Online Published 30.06.2020

DOI: $10.29133 /$ yyutbd.689385

\section{Keywords}

Bacteria,

Bitlis,

Microfungi,

Pesticides,
Abstract: Agricultural areas are important ecological environments with chemical inputs via human intervention. The presence of this type of natural areas is important for human as well as other species. This research was conducted to determine the effects of Satellite 20 WP, Status 330 E, Pesos 100 EC and Pentran 22 E pesticides, which are widely used in agricultural fields of Bitlis, on non-target soil nematodes, aerobic mesophilic bacteria, microfungi populations and $\mathrm{pH}$. The study was repeated (six times) according to variance analysis method (under invitro conditions). According to the variance analysis, the Period $\times$ Treatment interactions are important for $\mathrm{pH}$, plant-parasitic and fungivore nematodes respectively ( $\mathrm{P}=0.007 ; \mathrm{P}=0.008 ; \mathrm{P}=0.000)$, for omnivore-predator, bacterivore and total nematodes, on the other hand, $(\mathrm{P}=0.000 ; \mathrm{P}=0.000 ; \mathrm{P}=0.000)$ both period and the main effect of the treatments were statistically significant $(\mathrm{P}=0.046 ; \mathrm{P}=0.017$; 
Soil, Nematode.
$\mathrm{P}=0.009)$. Based on the profile analysis; $\mathrm{pH}$ increased especially in Satellite $20 \mathrm{WP}$ treatment, although the number of aerobic mesophilic bacteria increased in the control treatment, it decreased in all pesticide treatments; the number of microfungi increased in Pesos 100 EC treatment but decreased in other treatments; plantparasitic, fungivore and total nematode count decreased in all pesticide treatments; omnivore-predator and bacterivore nematodes were found to be partially affected. As a result, it has been determined that the used pesticides have positive or negative effects depending on the parameters considered.

\begin{abstract}
${ }^{* *} \mathrm{Bu}$ çalışma, "Bitlis ilinde tarımsal faaliyetlerde kullanılan bazı pestisitlerin toprak nematodları ve mikroorganizmaları üzerindeki etkilerinin araştırılması" adlı yüksek lisans tezinin bir bölümünü oluşturmaktadır. Ayrıca 3. Uluslararası Mardin Artuklu Bilimsel Araştırmalar Kongresi’nde (18-19 Ocak 2020) sözlü bildiri olarak sunulmuştur.
\end{abstract}

\title{
1. Giriş
}

Tarımsal alanlar, şüphesiz insanlar için önemli olduğu kadar bu ortamı paylaşan mikrodan makroya tüm canlılar için önemlidir. Bu alanların, geleceği ve verimi doğru kullanılmalarına bağlıdır. Hussain ve ark. (2009), pestisitler tarımsal faaliyetlerde zararlı kontrol stratejilerinin bir parçası olarak yaygın bir şekilde kullanılmaktadır. Al-Ani ve ark. (2019), hızla büyüyen insan nüfusunun paralelinde, mahsul üretimini en üst düzeye çıkarmak için kullanılan pestisitler büyük bir çevresel kaygıya yol açmaktadır. Ülkemizde, 1979-2007 yılları arasında kullanılan tarım ilaçlarının tüketimi iniş ve çıkışlara rağmen \%270 oranında artmış (Özbek ve Fidan, 2014), 2017'de kullanılan toplam tarım ilacı (pestisit), 2016’ya göre \%8.08 oranında artarak 54.098 tona ulaşmıştır (Anonim, 2019a). Bitlis İli'nin tarım potansiyeli, bölgesinde önemli bir yere sahiptir (Anonim, 2019b). Arora ve ark. (2019), kimyasal pestisitlerin gelişigüzel kullanımı toprak ortamını bozar ve toprak mikroflorası, fauna, flora ve toprağın fizikokimyasal özelliklerini etkilediğini ifade etmişlerdir. Yardim ve Edwards (1998), insektisit, fungisit ve herbisit karışımlarını uyguladıkları domates (Lycopersicon esculentum L.) tarla denemesinde, trofik gruplarına göre nematodların olumlu ve olumsuz tepkiler verdiklerini bildirmişlerdir. Römbke ve ark. (2009), Benomyl ve Chlorpyrifos karışımını uyguladıkları toprakta nematod popülasyonunun en çok \%48 oranında azaldığını bulmuşlardır. Koç (2017), buğday agro-ekosisteminde kullandığı pestisitlerin toprak nematodları üzerindeki etkilerine yönelik yaptığı uyum analizlerinde anlamlı ilişkiler tespit etmiştir. Ören ve ark. (2009), Safomyl 50 WP, Decis EC 25 ve Tefralin EC'nin toprak mikrobiyotasında bulunan bakteri ve maya-küf üzerinde farklı etkiler gözlemlemişlerdir. Küçük ve ark. (2016), çalışmalarında kullandıkları pestisitlerden hareketle, zararlı ile mücadelede fungisitlerin kullanılmasının kaçınılmaz olduğunu ve bundan dolayı kullanılacak fungisitlerin toprak mikroorganizmalarına etkisi dikkate alınarak, toksik olmayan, mikroorganizmalar tarafından hızlı ayrışabilen ve çevresel kalıntılar bırakmayan maddeler ihtiva etmesinin çevre ve canlı yaşamı açısından hayati önem taşıdığını ifade etmişlerdir. Koç ve Yardım (2019), buğday agro-ekosisteminde yaptıkları pestisit uygulamalarının toprakta bulunan fungal ile bakteriyel mikroorganizmaları önemli düzeylerde etkilemediğini saptamışlardır. Wesley ve ark. (2017), Thionex, Best ve DDforce insektisitlerinin farklı konsantrasyonlarını uyguladıkları toprak örneklerinde; ilaç çeşidi, dozu ve dikkate alınan parametrelere göre farklı sonuçlara ulaşmışlardır. Ubuoh ve ark. (2012), herbisit Glifosfat'ın mikrofungus ve bakteri türlerine etkilerini gözlemlemek için yaptıkları ilaç uygulamasında; kontrol ile karşılaştırıldığında toprakta bulunan mikrobiyal popülasyonda ciddi azalmaya neden olduğunu ortaya koymuşlardır. Lo (2010), pestisit yapılarının farklı olmasından ötürü çeşitli toprak mikroorganizma grupları üzerindeki etkisinin kolayca tahmin edilemediğini, bazı pestisitlerin mikroorganizmaların büyümesini uyarırken, diğer pestisitlerin depresif etkilerini olduğunu veya mikroorganizmalar üzerinde hiçbir etkisinin olmadığını beyan etmiştir. Al-Ani ve ark. (2019), Glifosat \%48, Miraj (Alphacypermethrin \%10) ve Malathion (\%50 WP)'un farklı dozlarını uyguladıkları topraktaki bakteri, mikrofunguslar ve aktinomisetlerin mikrobiyal aktivitelerini ve sayısını olumsuz etkilediğini önemli ölçüde azalttığını bulmuşlardır. Heinonen-Tanski ve ark. (1989), şeker pancarı alanında kullandıkları pestisitlerden toprak mikroorganizmalarının bazı durumlarda etkilendiğini, ancak her durumda etkilenmediğini saptamışlardır. Yousaf ve ark. (2013), Pendimethaline, Trifluralin, Glifosfat, 2,4-D ve MCPA (Chwastox) gibi yaygın olarak kullanılan pestisitlerin türüne göre büyük farklılıklar gösterdiğini bildirmişlerdir. Arora ve Sahni (2016), kimyasal pestisitlerin toprak mikroorganizmalarının 
aktivitelerini bozduğunu ve bu nedenle toprağın beslenme kalitesini etkileyebileceğini, mikroorganizmaların farklı pestisitlere, farklı tepkiler verdiğini ve nihayetinde ciddi ekolojik sonuçlara yol açabileceğini öngörmüşlerdir. Johns (2017), eğer tarımsal üretim büyüyen bir dünya nüfusunun ihtiyaçlarını karşılayacaksa, toprak mikrobiyolojisinin daha iyi anlaşılması gerektiğini ve birçok bölgede, sağlıklı mikroorganizma popülasyonlarının tarımsal uygulamalar tarafından hala tehdit altında olduğunu ve teşvik edilmediğini ifade etmiştir. Bitlis İli'nde 2018 yılında, $18.340 \mathrm{~kg}$-lt pestisit [(insektisit 4.224 kg-lt), (fungusit 2.434 kg-lt), (herbisit 10.485 kg-lt), (akarisit 296 kg-lt), (rodentisit $401 \mathrm{~kg}-\mathrm{lt}$ ) ve (diğer pestisitler $500 \mathrm{~kg}$-lt)] kullanılmıştır. 2017 y1lına göre, dünya ve Türkiye ortalamasının aksine Bitlis İli’nde en çok herbisit kullanılmış, ülkemizde az pestisit tüketiminin yapıldığg iller arasında olduğu görülmüştür (Güven ve Koç, 2019).

Bu çalı̧̧ma, Bitlis İli tarımsal alanlarda yaygın kullanılan Satellite 20 WP, Status 330 E, Pesos 100 EC ve Pentran 22 E pestisitlerinin hedef olmayan toprak canlılarından nematod, aerobik mezofilik bakteri, mikrofungus popülasyonları ve toprak pH'sına etkilerini tespit etmek amacıyla yapılmıştır.

\section{Materyal ve Yöntem}

$\mathrm{Bu}$ çalışma, 2019 yılında laboratuvar şartlarında (ortalama sıcaklık: $22.4^{\circ} \mathrm{C}$ ) yapılmıştır. Çalışmada kullanılan toprak Bitlis İli'nde tarımsal faaliyetler için kullanılmamış mera ortamından (Enl.: 38²3'47.6", Boy.: 4206'52.4") ve 0-30 cm derinlikten (Koç, 2019; Koç ve Yardım, 2019), 12 Mayıs 2019'da alınmıştır. Alınan toprak örnekleri, 2 mm'lik elekten geçirilerek çalışma yapılıncaya kadar buzdolabında $+4^{\circ} \mathrm{C}$ 'de temiz plastik poşetlerde muhafaza edilmiştir. Toprağın tekstürü, Bouyoucos (1951)'e göre (kil oran1; \%3, silt oran1; \%27, kum oran1; \%70, kireç oran1; \%1.84, pH; 8.1, EC; 291 $\mu \mathrm{S} / \mathrm{cm}^{-1}$ ); toprağın $\mathrm{pH}$ 'sı (toprak reaksiyonu), Jackson (1958)'a göre ve toprağın orantılı nem miktarları, Craze (1990)'e göre [uygulama öncesi ve sonrası surasıyla (\%11.11, \%16.04)] belirlenmiştir. Bitlis İli’nde yaygın olarak kullanılan pestisitlerin belirlenmesinde; Bitlis İl Tarım ve Orman Müdürlügü, zirai ilaç bayii ve çiftçilerden sorularak tespit edilmiştir. Pestisit gruplarını (insektisit, herbisit ve fungisit gibi) temsilen birer tane pestisit olmak üzere toplamda dört adet [Satellite 20 WP (\%20 Pyridaben), Status 330 E (330 g/l Pendimethalin), Pesos 100 EC (100 g/L Penconazole) ve Pentran 22 E (227 g/l Chlorpyrifos-methyl)] kullanılmıştır (Şekil 1a). Deneme, tekrarlı ölçümlerde varyans analizi yöntemine göre altı tekerrürlü olarak yürütülmüş̧ür (Şekil 1c). Belirlenen pestisitler, enjektör yardımı ile önerilen dozda [Satellite $20 \mathrm{WP}(0.045 \mathrm{~g}+100 \mathrm{ml}$ saf su), Status $330 \mathrm{E}(0.060 \mathrm{ml}+100 \mathrm{ml} \mathrm{saf}$ su), Pesos $100 \mathrm{EC}$ $(0.030 \mathrm{ml}+100 \mathrm{ml}$ saf su) ve Pentran $22 \mathrm{E}(0.045 \mathrm{ml}+100 \mathrm{ml} \mathrm{saf} \mathrm{su})]$ bir kg toprak konulmuş saksılara 10 ml'lik çözelti şeklinde püskürtülerek verilmiştir (Şekil 1b). Kontrol grubuna, sadece saf su verilmiştir. Toprağın nemini korumak için, saksılara ikişer gün ara ile $75 \mathrm{ml}$ 'lik şebeke suyu verilmiştir. Deneme iki ay sürmüş (9 Ekim-10 Aralık 2019) ve toprak örnekleri pestisit uygulamasından önce ve sonra alınmıştır. Alınan örneklerde, mikrofungus, aerobik mezofilik bakteri ve trofik gruplarına göre nematod sayımlarının yanı sıra $\mathrm{pH}$ ve nem ölçümleri de yapılmıştır.

Toplam mikrofungus ve aerobik mezofilik bakteri sayısının tespiti Benson (2001)'a göre yapılmıştır. Bakteri sayımı için, Plate Count Agar (PCA) ve mikrofungus sayımı için RosebengaleKloramfenikol Agar besiyerleri kullanılmıştır (Şekil 1d, e, f). Nematodların ekstraksiyonu ve sayımında Geliştirilmiş-Baermann Huni Yöntemi kullanılmış (Baermann, 1917; Whitehead ve Hemming, 1965; Southey, 1986), mikroskopun objektifinde $(\times 10)$ trofik düzeylerine göre sayımları Yeates (1971) ve Yeates ve ark. (1993)'e göre (Şekil 2) yapılmıştır (Yıldız ve ark., 2017; Koc, 2019).

Yapılan pestisit uygulamalarının (uygulama öncesi ve sonrası) etkilerinin araştırılmasında Tekrarlanan Ölçümlü Varyans Analizi ve Profil Analizi Tekniklerinden yararlanılmıştır (Mendeş ve ark., 2007; Mendeş, 2012). İstatistik analizlerin yapılmasında SPSS (ver. 22.0) istatistik paket programı kullanılmıştır. 

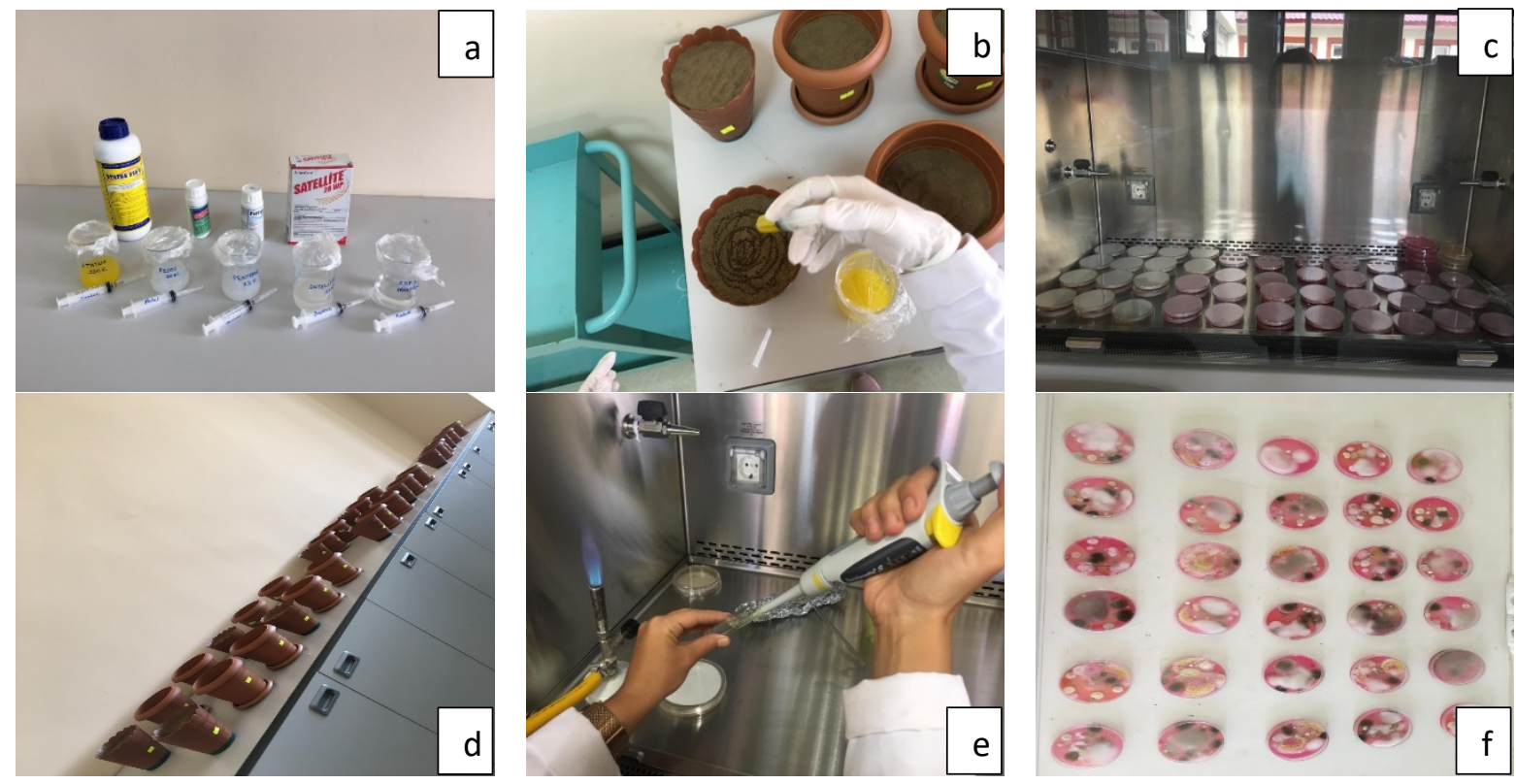

Şekil 1. Denemede kullanılan pestisitler (a), pestisit uygulamasının yapılması (b), hazırlanmış besiyerleri (c), deneme görüntüsü (d), besiyerine ekim işleminin yapılması (e) ve sayım aşamasındaki mikrofungusların görüntüsü (f).
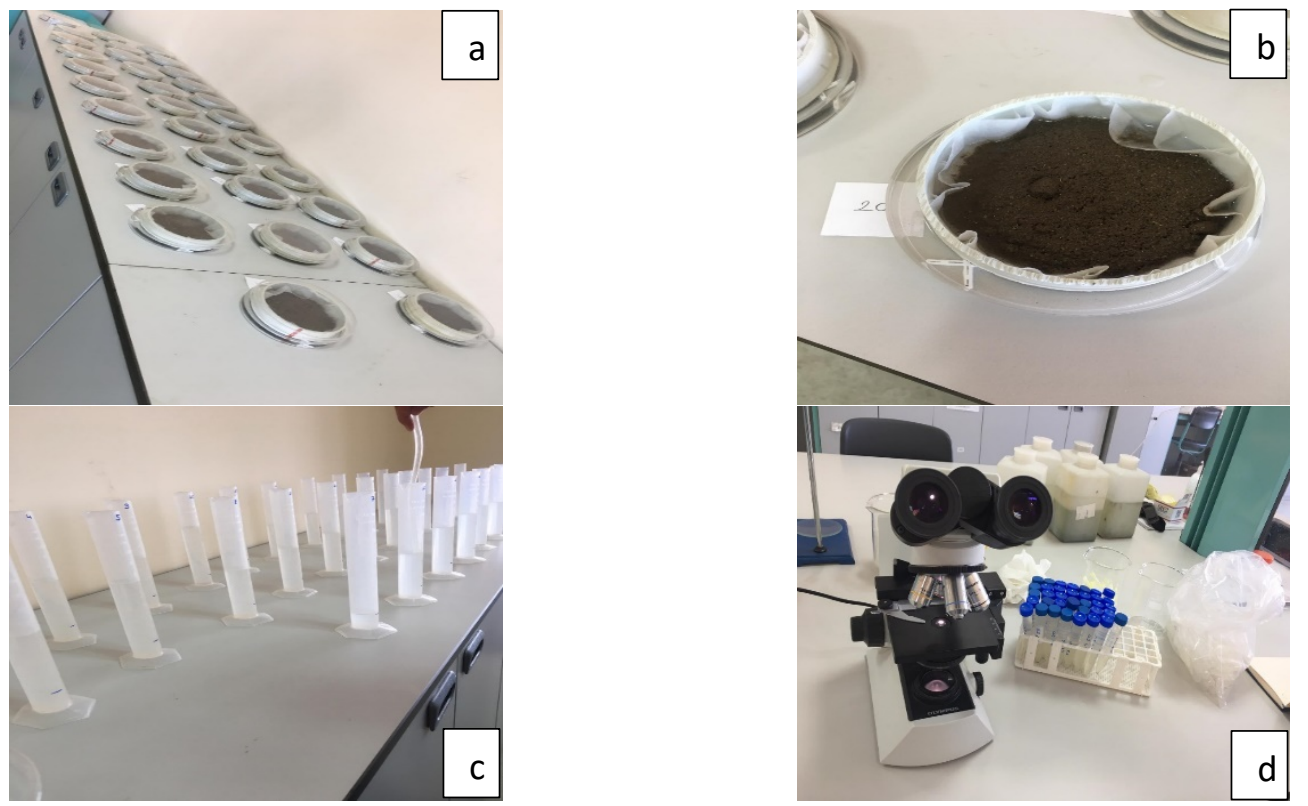

Şekil 2. Toprak örneği bırakılmış elek düzeneği (a), iki gün şebeke suyunda bırakılmış örnek (b), mezürlere alınmış ekstraktlar (c) ve nematodların mikroskopun objektifinde $(\times 10)$ sayımı (d).

\section{Bulgular}

\subsection{Pestisit uygulamalarının toprak pH parametresine etkisi}

Yapılan tekrarlanan ölçümlü varyans analizi sonucunda Periyot $\times$ Uygulama interaksiyonu istatistiksel olarak önemli $(\mathrm{P}=0.007)$ bulunmuştur. Uygulama sonrası, özellikle kontrol ve Satellite 20 WP uygulamalarında önemli farklılıklar görülmüştür (Çizelge 1, Şekil 3). 
Çizelge 1. Pestisit uygulanmış toprakların $\mathrm{pH}$ değerleri bakımından tanıtıcı istatistikler

\begin{tabular}{lccc}
\hline \multicolumn{1}{c}{$\begin{array}{c}\text { Pestisit } \\
\text { Uygulamalar1 }\end{array}$} & $\mathrm{N}$ & Uygulama Öncesi & Uygulama Sonras1 \\
\cline { 3 - 4 } \multicolumn{1}{c}{ Satellite 20 WP } & 6 & Ort. \pm SH & Ort. \pm SH \\
Status 330 E & 6 & $8.215 \pm 0.039 \mathrm{Ba}$ & $8.441 \pm 0.022 \mathrm{Aa}$ \\
Pesos 100 EC & 6 & $8.265 \pm 0.019 \mathrm{Aab}$ & $8.343 \pm 0.020 \mathrm{Aa}$ \\
Pentran 22 E & 6 & $8.281 \pm 0.011 \mathrm{Ab}$ & $8.360 \pm 0.018 \mathrm{Aa}$ \\
Kontrol & 6 & $8.233 \pm 0.010 \mathrm{Aab}$ & $8.400 \pm 0.017 \mathrm{Aa}$ \\
Toplam & 30 & $8.257 \pm 0.023$ & $8.395 \pm 0.016 \mathrm{Aa}$ \\
\hline
\end{tabular}

Not 1: Aynı satırda farklı büyük harflerle gösterilen ortalamalar arasındaki farklar önemlidir.

Not 2: Aynı sütunda farklı küçük harflerle gösterilen ortalamalar arasındaki farklar önemlidir.

Profil analizi sonuçları incelendiğinde genel olarak 2. periyotta (uygulama sonrası) ölçülen pH değerlerinin daha yüksek olduğu görülüyorsa da 1., 4., ve 5. uygulamaların pH değerleri arasında önemli farkların bulunduğu, ancak 2. ve 3. uygulamaların $\mathrm{pH}$ değerleri arasında önemli farkların bulunmadığ görülmektedir (Şekil 3).

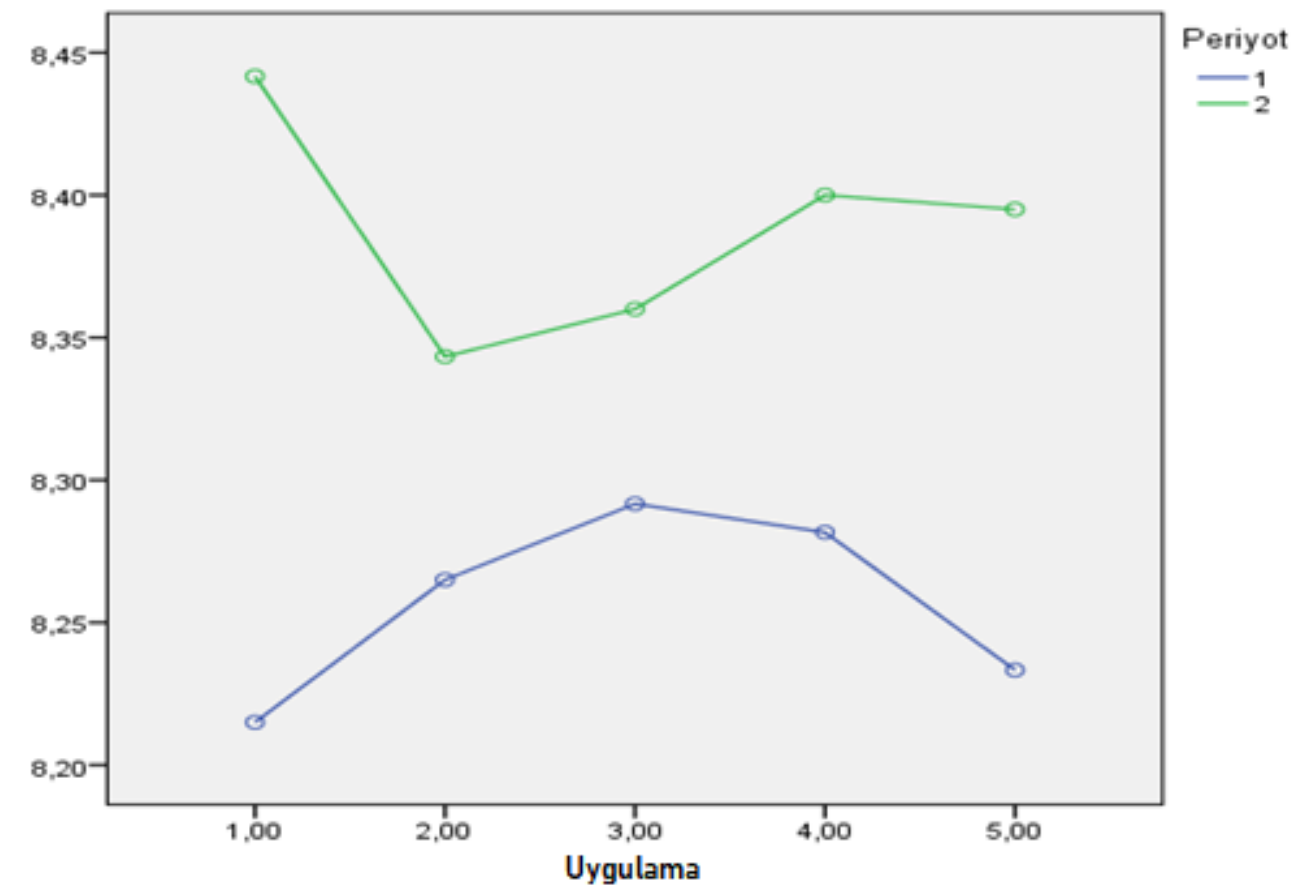

Şekil 3. Pestisit uygulanmış toprakların pH değerleri bakımından profil analizi.

${ }^{*}$ Periyot 1: Uygulama öncesi, Periyot 2: Uygulama sonras1

*Uygulama 1: Satellite 20 WP, Uygulama 2: Status 330 E, Uygulama 3: Pesos 100 EC, Uygulama 4: Pentran 22 E, Uygulama

5: Kontrol

\subsection{Pestisit uygulamalarının toprak aerobik mezofilik bakteri sayısına etkisi}

Yapılan tekrarlanan ölçümlü varyans analizi sonucunda ne Periyot $\times$ Uygulama interaksiyon etkisi $(\mathrm{P}=0.302)$, ne de periyot ve uygulamaların ana etkileri $(\mathrm{P}=0.089 ; \mathrm{P}=0.069)$ istatistiksel olarak önemli bulunmamıştır (Çizelge 2).

Her ne kadar yapılan varyans analizlerinde yapılan uygulamalar arasında fark görülmese de Profil analizi sonuçları incelendiğinde, 5. uygulamanın (kontrol) aksine özellikle 1. uygulama (Satellite 20 WP) başta olmak üzere diğer tüm uygulamalarda aerobik mezofilik bakteri sayısının azaldığı görülmüştür (Şekil 4). 
Çizelge 2. Pestisit uygulanmış toprakların aerobik mezofilik bakteri sayısı bakımından tanıtıcı istatistikler

\begin{tabular}{lccc}
\hline \multicolumn{1}{c}{ Pestisit } & $\mathrm{N}$ & Uygulama Öncesi & Uygulama Sonras1 \\
\cline { 3 - 4 } \multicolumn{1}{c}{ Uygulamalar1 } & & Ort. \pm SH & Ort. \pm SH \\
\hline Satellite 20 WP & 6 & $2370.0 \times 10^{4} \pm 426.0 \times 10^{4}$ & $653.3 \times 10^{4} \pm 431.7 \times 10^{4}$ \\
Status 330 E & 6 & $2703.3 \times 10^{4} \pm 218.6 \times 10^{4}$ & $1828.3 \times 10^{4} \pm 1127.5 \times 10^{4}$ \\
Pesos 100 EC & 6 & $1795.0 \times 10^{4} \pm 225.2 \times 10^{4}$ & $916.6 \times 10^{4} \pm 310.2 \times 10^{4}$ \\
Pentran 22 E & 6 & $2703.3 \times 10^{4} \pm 513.3 \times 10^{4}$ & $1485.0 \times 10^{4} \pm 1033.7 \times 10^{4}$ \\
Kontrol & 6 & $2646.6 \times 10^{4} \pm 288.3 \times 10^{4}$ & $3645.0 \times 10^{4} \pm 902.5 \times 10^{4}$ \\
Toplam & 30 & $2423.0 \times 10^{4} \pm 356.7 \times 10^{4}$ & $1705.6 \times 10^{4} \pm 885.5 \times 10^{4}$ \\
\hline
\end{tabular}

Not: Bakteri sayısı bakımından farklar önemli bulunmadığından herhangi bir harflendirme yapılmamıştır.

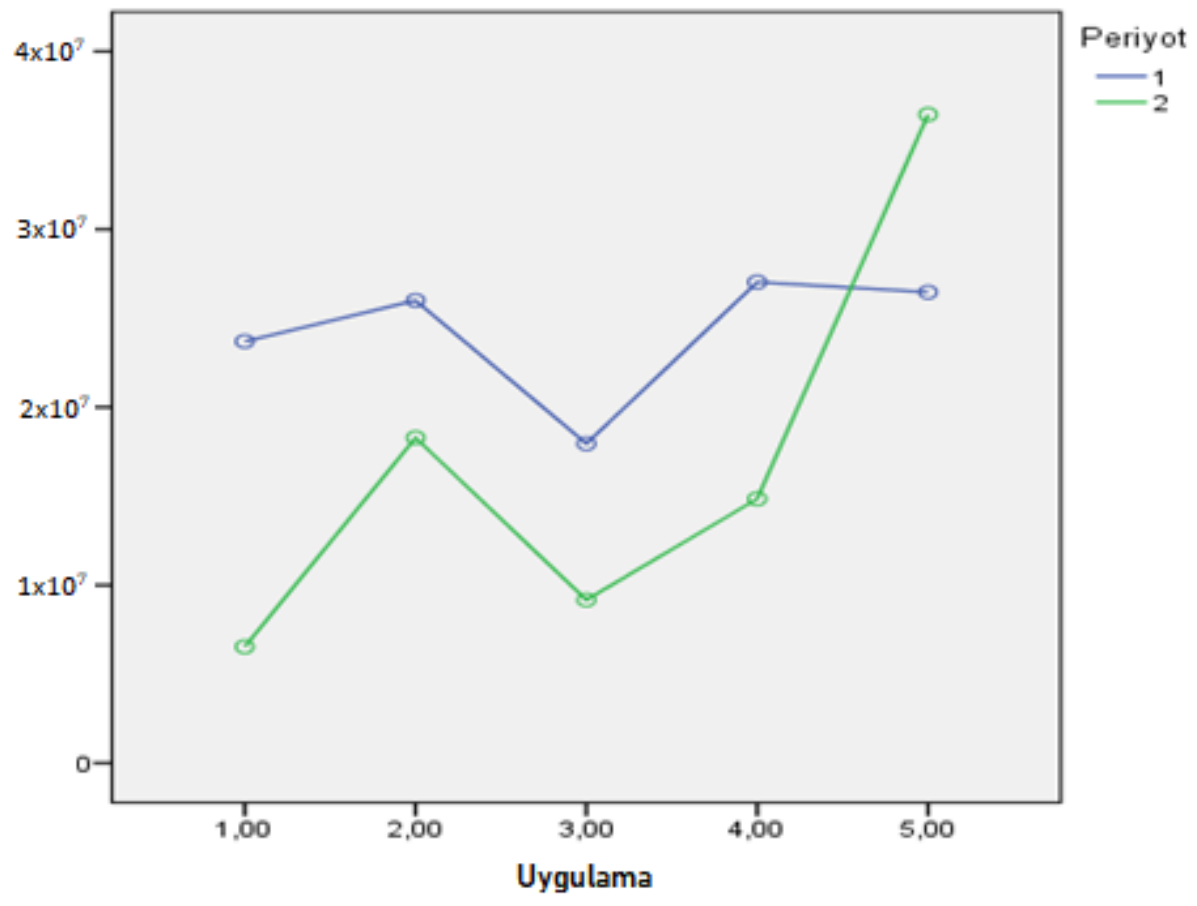

Şekil 4. Pestisit uygulanmış toprakların aerobik mezofilik bakteri sayısı bakımından profil analizi. *Periyot 1: Uygulama öncesi, Periyot 2: Uygulama sonras1

*Uygulama 1: Satellite 20 WP, Uygulama 2: Status 330 E, Uygulama 3: Pesos 100 EC, Uygulama 4: Pentran 22 E, Uygulama 5: Kontrol

\subsection{Pestisit uygulamalarının toprak mikrofungus sayısına etkisi}

Toprak örneklerinde altısı tür (Trichoderma harzianum, Aspergillus niger, Penicillium italicum, Fusarium oxysporum, Penicillium digitatum ve Rhizopus stolonifer) ikisi cins düzeyinde (Mucor spp., ve Alternaria spp.) olmak üzere toplamda sekiz mikrofungus izolatı tespit edilmiştir.

Yapılan tekrarlanan ölçümlü varyans analizi sonucunda ne Periyot $\times$ Uygulama interaksiyon etkisi $(\mathrm{P}=0.309)$, ne de periyot ve uygulamaların ana etkileri $(\mathrm{P}=0.171 ; \mathrm{P}=0.884)$ istatistiksel olarak önemli bulunmamıştır (Çizelge 3). Profil analizi sonuçları incelendiğinde, varyans analizleri sonucuna göre fark görülmemiş olsa da 3. uygulama (Pesos 100 EC) hariç tüm uygulamalarda mikrofungus sayısının azaldığı ve 5. uygulamaya (kontrol) göre özellikle 1. ve 4. uygulamalarda azalmanın daha çok olduğu saptanmıştır (Şekil 5). 
Çizelge 3. Pestisit uygulanmış toprakların mikrofungus sayısı bakımından tanıtıcı istatistikler

\begin{tabular}{lccc}
\hline \multicolumn{1}{c}{$\begin{array}{c}\text { Pestisit } \\
\text { Uygulamaları }\end{array}$} & $\mathrm{N}$ & Uygulama Öncesi & Uygulama Sonras1 \\
\cline { 3 - 4 } & & Ort. \pm SH & Ort. \pm SH \\
\hline Satellite 20 WP & 6 & $2750.000 \pm 698.450$ & $1833.333 \pm 275.277$ \\
Status 330 E & 6 & $2150.000 \pm 332.415$ & $1700.000 \pm 182.574$ \\
Pesos 100 EC & 6 & $1966.666 \pm 245.854$ & $3083.333 \pm 1334.520$ \\
Pentran 22 E & 6 & $2850.000 \pm 341.320$ & $1816.666 \pm 147.007$ \\
Kontrol & 6 & $2400.000 \pm 323.522$ & $2083.333 \pm 221.233$ \\
Toplam & 30 & $2423.333 \pm 414.074$ & $2103.333 \pm 618.162$ \\
\hline
\end{tabular}

Not: Mikrofungus sayısı bakımından farklar önemli bulunmadığından herhangi bir harflendirme yapılmamıştır.

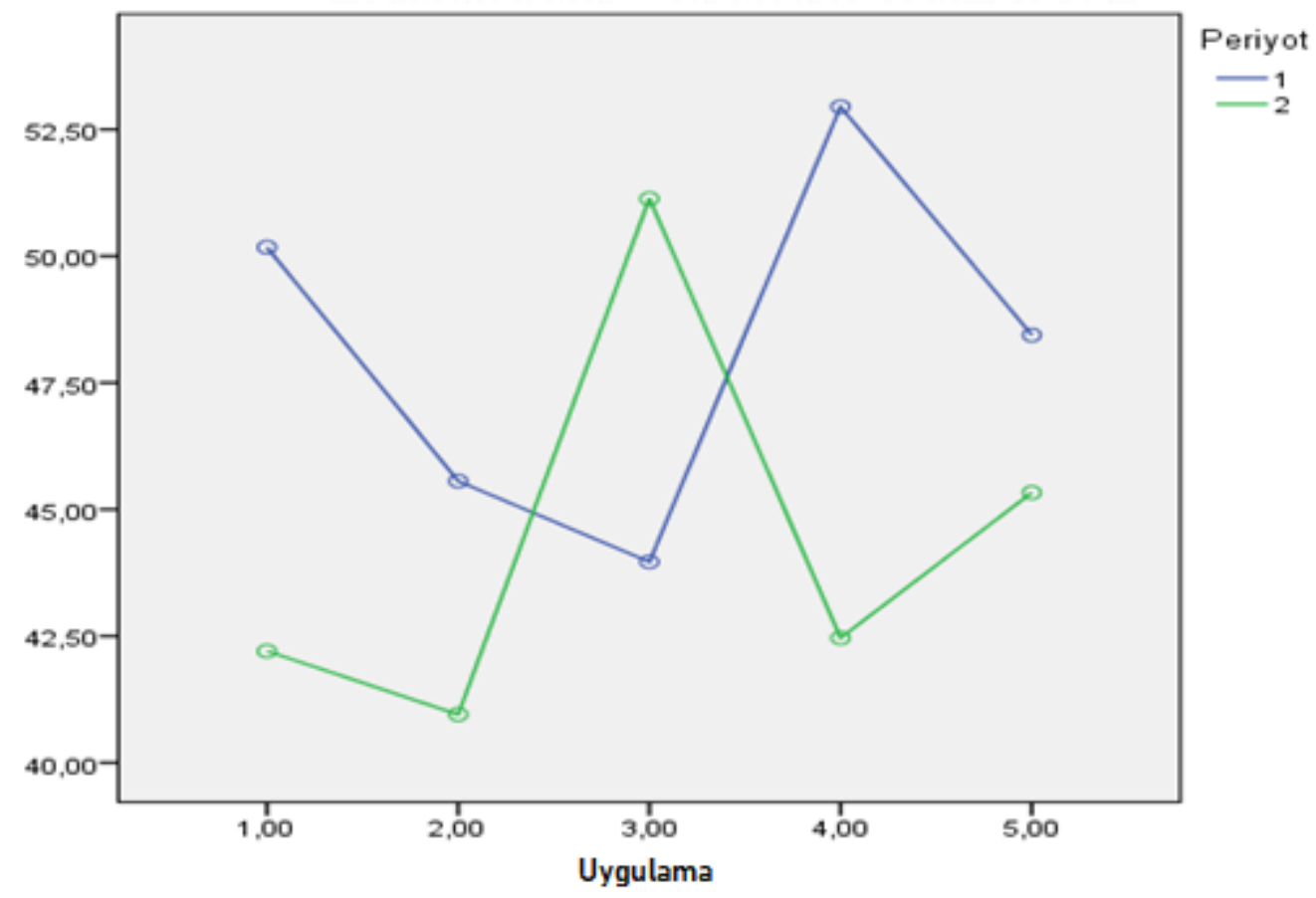

Şekil 5. Pestisit uygulanmış toprakların mikrofungus sayısı bakımından profil analizi.

"Periyot 1: Uygulama öncesi, Periyot 2: Uygulama sonras1

*Uygulama 1: Satellite 20 WP, Uygulama 2: Status 330 E, Uygulama 3: Pesos 100 EC, Uygulama 4: Pentran 22 E, Uygulama 5: Kontrol

\subsection{Pestisit uygulamalarının bitki paraziti nematod sayısına etkisi}

Yapılan tekrarlanan ölçümlü varyans analizi sonucunda Periyot $\times$ Uygulama interaksiyon etkisi istatistiksel olarak önemli bulunmuştur $(\mathrm{P}=0.008)$. Dolayısıyla yapılan uygulamaların bitki paraziti nematod sayısına etkisi periyotlara göre önemli düzeylerde değişmiştir (Çizelge 4).

Çizelge 4. Pestisit uygulanmış toprakların bitki paraziti nematod sayısı bakımından tanıtıcı istatistikler

\begin{tabular}{lccc}
\hline \multicolumn{1}{c}{$\begin{array}{c}\text { Pestisit } \\
\text { Uygulamaları }\end{array}$} & $\mathrm{N}$ & Uygulama Öncesi & Uygulama Sonras1 \\
\cline { 3 - 4 } & & Ort. $\pm \mathrm{SH}$ & Ort. $\pm \mathrm{SH}$ \\
\hline Satellite 20 WP & 6 & $17.000 \pm 2.463 \mathrm{Aa}$ & $1.666 \pm 0.333 \mathrm{Bb}$ \\
Status 330 E & 6 & $17.333 \pm 1.837 \mathrm{Aa}$ & $2.333 \pm 0.494 \mathrm{Bb}$ \\
Pesos 100 EC & 6 & $19.000 \pm 1.125 \mathrm{Aa}$ & $2.000 \pm 0.516 \mathrm{Bb}$ \\
Pentran 22 E & 6 & $17.333 \pm 1.229 \mathrm{Aa}$ & $3.000 \pm 1.095 \mathrm{Bb}$ \\
Kontrol & 6 & $18.000 \pm 2.683 \mathrm{Aa}$ & $7.333 \pm 0.802 \mathrm{Ba}$ \\
Toplam & 30 & $17.733 \pm 1.853$ & $3.266 \pm 1.082$ \\
\hline
\end{tabular}

Not 1: Aynı satırda farklı büyük harflerle gösterilen ortalamalar arasındaki farklar önemlidir.

Not 2: Aynı sütunda farklı küçük harflerle gösterilen ortalamalar arasındaki farklar önemlidir. 
Profil analizi sonuçları incelendiğinde 1. ve 2. periyotlar arasında farkın olduğu, 5. uygulamaya (kontrol) oranla diğer pestisit uygulamalarının bitki paraziti nematodlar üzerinde olumsuz etkide bulunduğu tespit edilmiştir (Şekil 6).

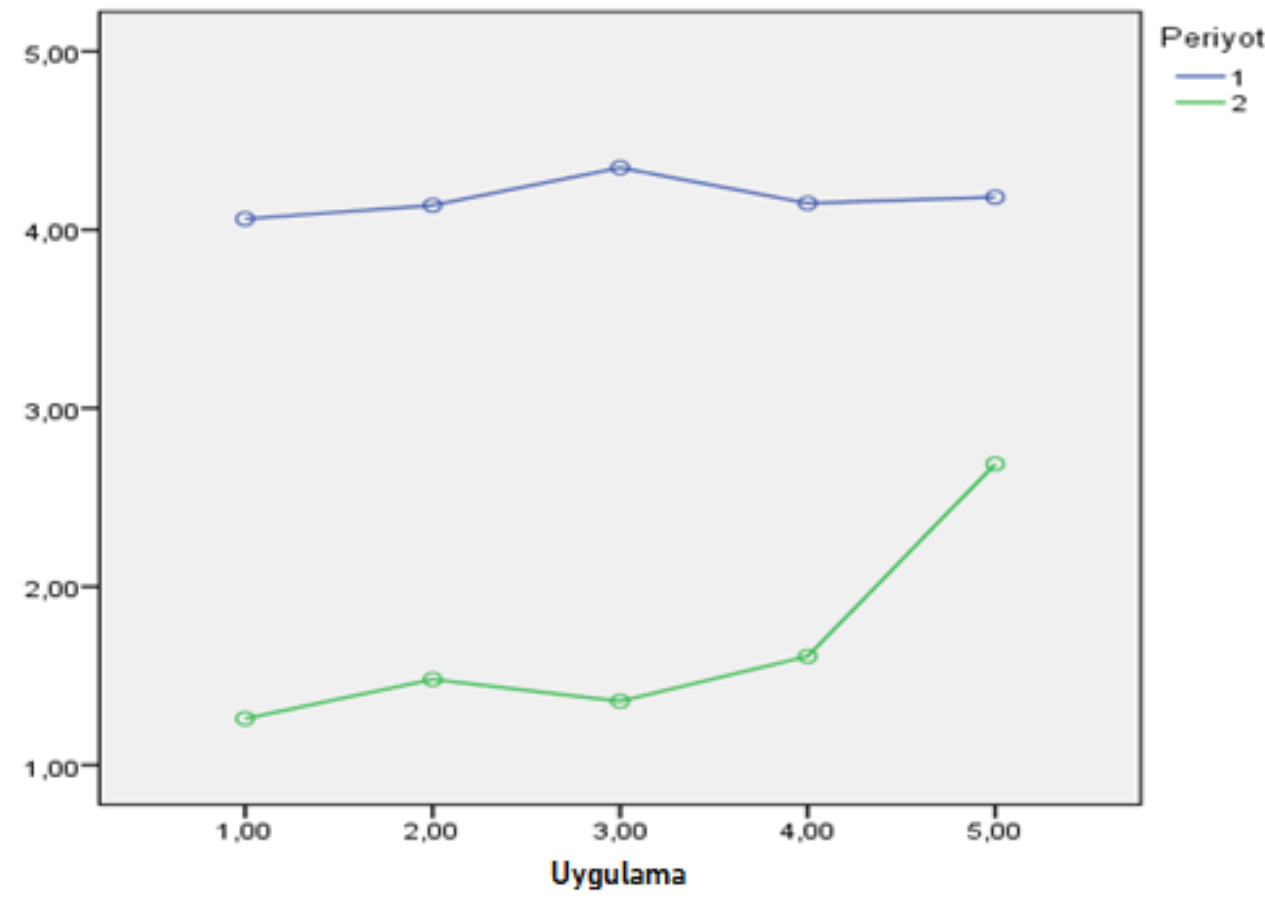

Şekil 6. Pestisit uygulanmış toprakların bitki paraziti nematod sayısı bakımından profil analizi.

*Periyot 1: Uygulama öncesi, Periyot 2: Uygulama sonrası

*Uygulama 1: Satellite 20 WP, Uygulama 2: Status 330 E, Uygulama 3: Pesos 100 EC, Uygulama 4: Pentran 22 E, Uygulama

5: Kontrol.

\subsection{Pestisit uygulamalarının fungivor nematod sayısına etkisi}

Yapılan tekrarlanan ölçümlü varyans analizi sonucunda sadece periyot etkisinin istatistiksel olarak önemli olduğu $(\mathrm{P}=0.000)$ görülmüştür (Çizelge 5).

Çizelge 5. Pestisit uygulanmış toprakların fungivor nematod sayısı bakımından tanıtıcı istatistikler

\begin{tabular}{lccc}
\hline & $\mathrm{N}$ & Uygulama Öncesi & Uygulama Sonrasi \\
\cline { 3 - 4 } & & Ort. \pm SH & Ort. \pm SH \\
\hline Satellite 20 WP & 6 & $4.833 \pm 0.833 \mathrm{~A}$ & $1.000 \pm 0.001 \mathrm{~B}$ \\
Status 330 E & 6 & $4.666 \pm 0.843 \mathrm{~A}$ & $1.166 \pm 0.166 \mathrm{~B}$ \\
Pesos 100 EC & 6 & $5.333 \pm 1.333 \mathrm{~A}$ & $1.000 \pm 0.000 \mathrm{~B}$ \\
Pentran 22 E & 6 & $6.333 \pm 1.201 \mathrm{~A}$ & $1.000 \pm 0.000 \mathrm{~B}$ \\
Kontrol & 6 & $7.166 \pm 2.372 \mathrm{~A}$ & $2.833 \pm 0.477 \mathrm{~B}$ \\
Toplam & 30 & $5.666 \pm 1.386$ & $1.400 \pm 0.365$ \\
\hline
\end{tabular}

Not 1: Aynı satırda farklı büyük harflerle gösterilen ortalamalar arasındaki farklar önemlidir.

Varyans analizleri sonucuna göre sadece periyotlar (uygulama öncesi ve sonras1) arasında fark görülse de yapılan profil analizi sonuçları incelendiğinde; kontrole (5. uygulama) göre tüm pestisit uygulamalarının fungivor nematodlar üzerinde olumsuz etkide bulunduğu görülmüştür (Şekil 7). 


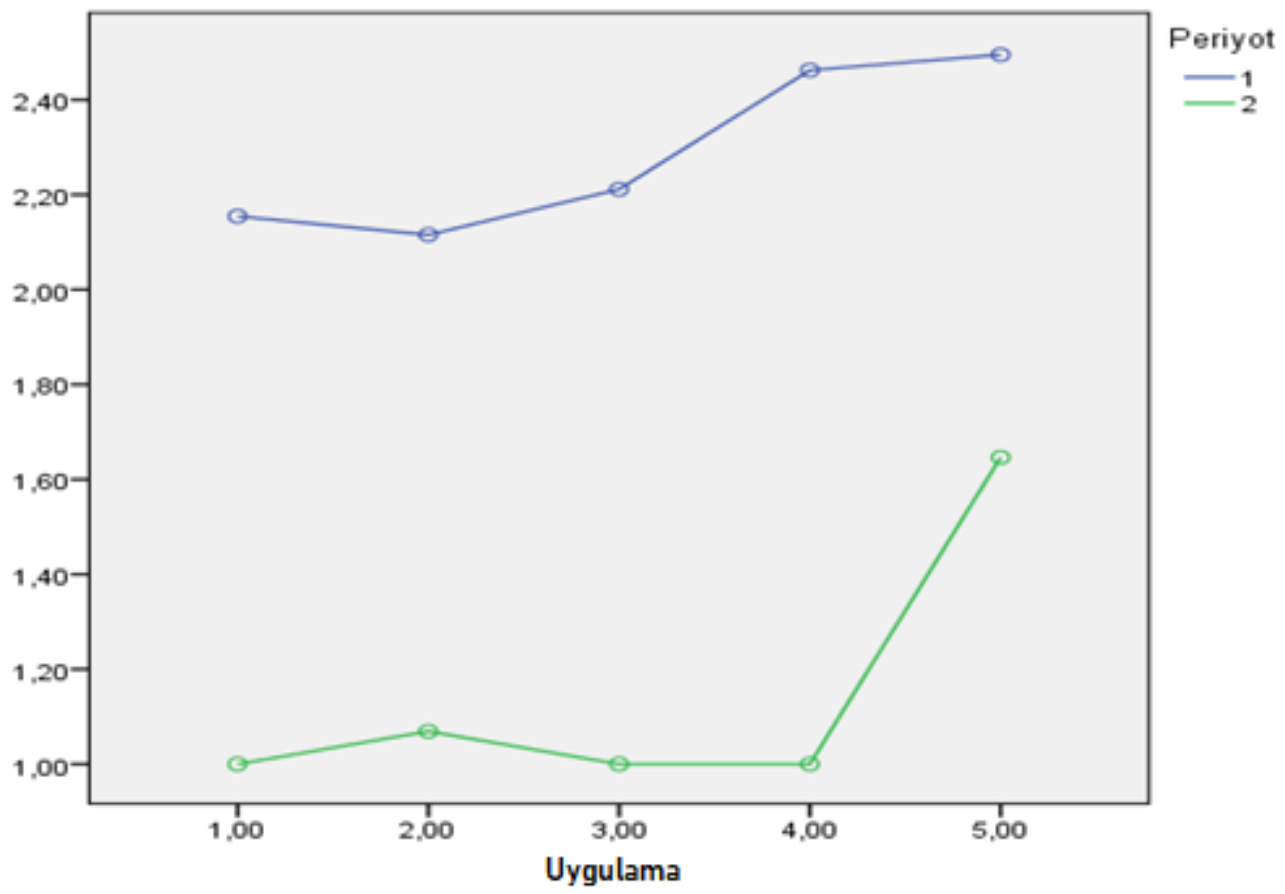

Şekil 7. Pestisit uygulanmış toprakların fungivor nematod sayısı bakımından profil analizi. *Periyot 1: Uygulama öncesi, Periyot 2: Uygulama sonras1

*Uygulama 1: Satellite 20 WP, Uygulama 2: Status 330 E, Uygulama 3: Pesos 100 EC, Uygulama 4: Pentran 22 E, Uygulama 5: Kontrol

\subsection{Pestisit uygulamalarının omnivor-avcı nematod sayısına etkisi}

Yapılan tekrarlanan ölçümlü varyans analizi sonucunda Periyot $\times$ Uygulama etkisi istatistiksel olarak önemli bulunmazken ( $\mathrm{P}=0.541)$, hem periyot $(\mathrm{P}=0.000)$ hem de uygulamaların ana etkisi $(\mathrm{P}=0.046)$ istatistiksel olarak önemli bulunmuştur (Çizelge 6). Yapılan uygulamalardan Satellite $20 \mathrm{WP}$ pestisit uygulaması haricinde diğer uygulamalarda farklılığın olduğu Çizelge 6 ve Şekil 8'de görülmektedir.

Çizelge 6. Pestisit uygulanmış toprakların omnivor-avcı nematod sayısı bakımından tanıtıcı istatistikler

\begin{tabular}{lccc}
\hline \multicolumn{1}{c}{$\begin{array}{c}\text { Pestisit } \\
\text { Uygulamalar }\end{array}$} & $\mathrm{N}$ & Uygulama Öncesi & Uygulama Sonras1 \\
\cline { 3 - 4 } \multicolumn{1}{c}{ Satellite 20 WP } & 6 & Ort. $\pm \mathrm{SH}$ & Ort. $\pm \mathrm{SH}$ \\
Status 330 E & 6 & $4.000 \pm 0.856 \mathrm{Ab}$ & $3.333 \pm 1.085 \mathrm{Aa}$ \\
Pesos 100 EC & 6 & $9.833 \pm 2.257 \mathrm{Aa}$ & $3.666 \pm 0.954 \mathrm{Ba}$ \\
Pentran 22 E & 6 & $13.666 \pm 2.800 \mathrm{Aa}$ & $4.166 \pm 1.013 \mathrm{Ba}$ \\
Kontrol & 6 & $11.333 \pm 1.977 \mathrm{Aa}$ & $4.333 \pm 0.954 \mathrm{Ba}$ \\
Toplam & 30 & $8.833 \pm 2.104 \mathrm{Ab}$ & $3.833 \pm 0.600 \mathrm{Ba}$ \\
\hline
\end{tabular}

Not 1: Aynı satırda farklı büyük harflerle gösterilen ortalamalar arasındaki farklar önemlidir.

Not 2: Aynı sütunda farklı küçük harflerle gösterilen ortalamalar arasındaki farklar önemlidir.

Profil analizi sonuçları incelendiğinde; kontrole (5. uygulama) göre özellikle 3. uygulamanın omnivor-avcı nematodlar üzerinde etkili olduğu saptanmıştır (Şekil 8). 


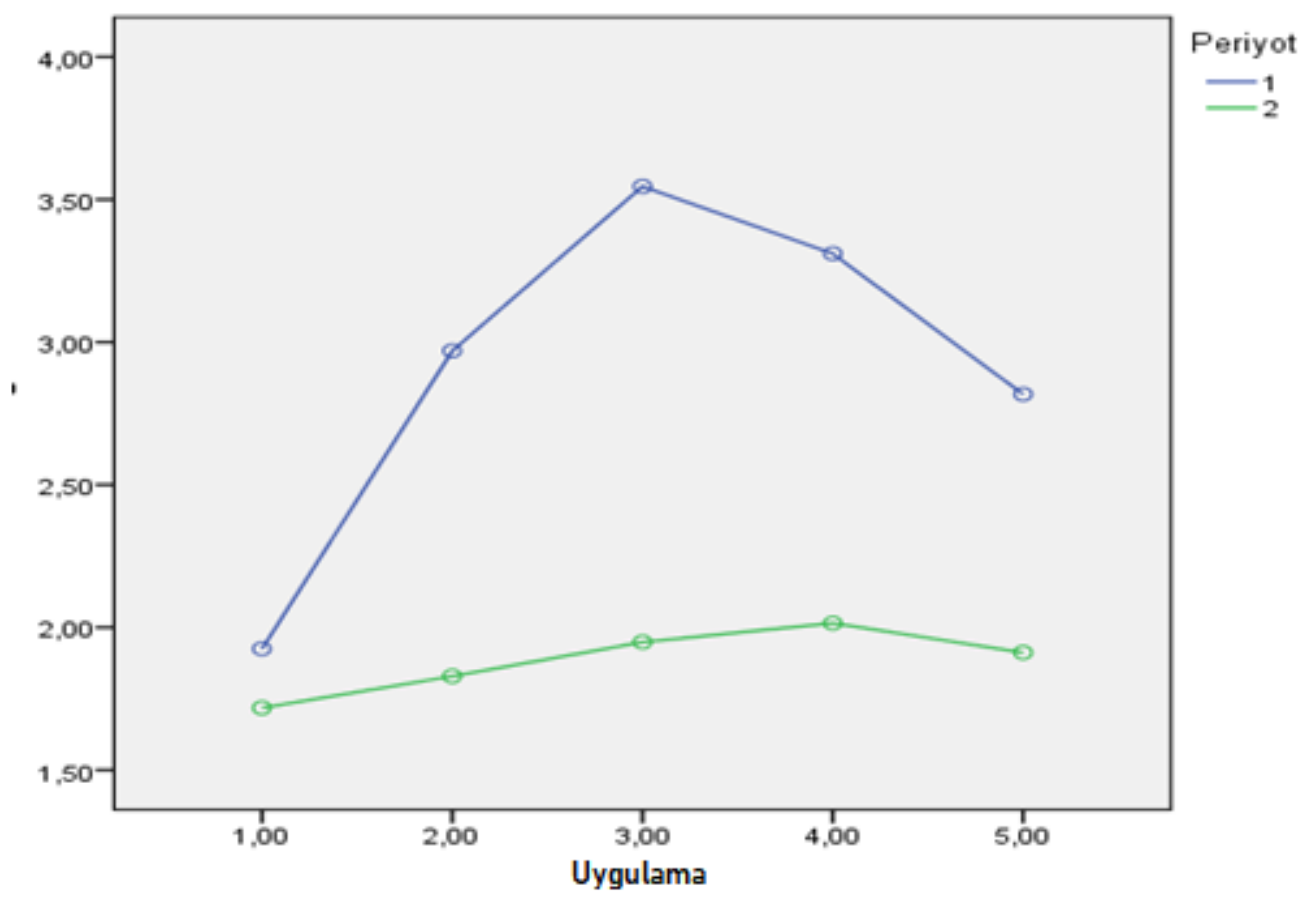

Şekil 8. Pestisit uygulanmış toprakların omnivor-avcı nematod sayısı bakımından profil analizi.

"Periyot 1: Uygulama öncesi, Periyot 2: Uygulama sonras1

"Uygulama 1: Satellite 20 WP, Uygulama 2: Status 330 E, Uygulama 3: Pesos 100 EC, Uygulama 4: Pentran 22 E, Uygulama

5: Kontrol

\subsection{Pestisit uygulamalarının bakterivor nematod sayısına etkisi}

Yapılan tekrarlanan ölçümlü varyans analizi sonucunda Periyot $\times$ Uygulama etkisi istatistiksel olarak önemli bulunmazken $(\mathrm{P}=0.442)$, hem periyot $(\mathrm{P}=0.000)$ hem de uygulamaların ana etkisi $(\mathrm{P}=0.017)$ istatistiksel olarak önemli bulunmuştur (Çizelge 7).

Çizelge 7. Pestisit uygulanmış toprakların bakterivor nematod sayısı bakımından tanıtıcı istatistikler

\begin{tabular}{lccc}
\hline \multicolumn{1}{c}{$\begin{array}{c}\text { Pestisit } \\
\text { Uygulamalar1 }\end{array}$} & $\mathrm{N}$ & Uygulama Öncesi & Uygulama Sonras1 \\
\cline { 3 - 4 } & & Ort. $\pm \mathrm{SH}$ & Ort. $\pm \mathrm{SH}$ \\
\hline Satellite 20 WP & 6 & $11.500 \pm 1.927 \mathrm{Ab}$ & $2.000 \pm 0.258 \mathrm{Bb}$ \\
Status 330 E & 6 & $9.000 \pm 1.693 \mathrm{Ab}$ & $4.000 \pm 1.483 \mathrm{Ba}$ \\
Pesos 100 EC & 6 & $10.666 \pm 1.333 \mathrm{Ab}$ & $2.500 \pm 0.718 \mathrm{Bab}$ \\
Pentran 22 E & 6 & $12.000 \pm 1.932 \mathrm{Aab}$ & $1.833 \pm 0.542 \mathrm{Bb}$ \\
Kontrol & 6 & $16.000 \pm 2.065 \mathrm{Aa}$ & $4.500 \pm 0.763 \mathrm{Ba}$ \\
Toplam & 30 & $11.833 \pm 1.935$ & $2.966 \pm 0.912$ \\
\hline
\end{tabular}

Not 1: Aynı satırda farklı büyük harflerle gösterilen ortalamalar arasındaki farklar önemlidir.

Not 2: Aynı sütunda farklı küçük harflerle gösterilen ortalamalar arasındaki farklar önemlidir.

Profil analizi sonuçları incelendiğinde uygulama öncesi ile sonrası ve uygulamalar arasında farkların olduğu tespit edilmiştir (Şekil 9). 


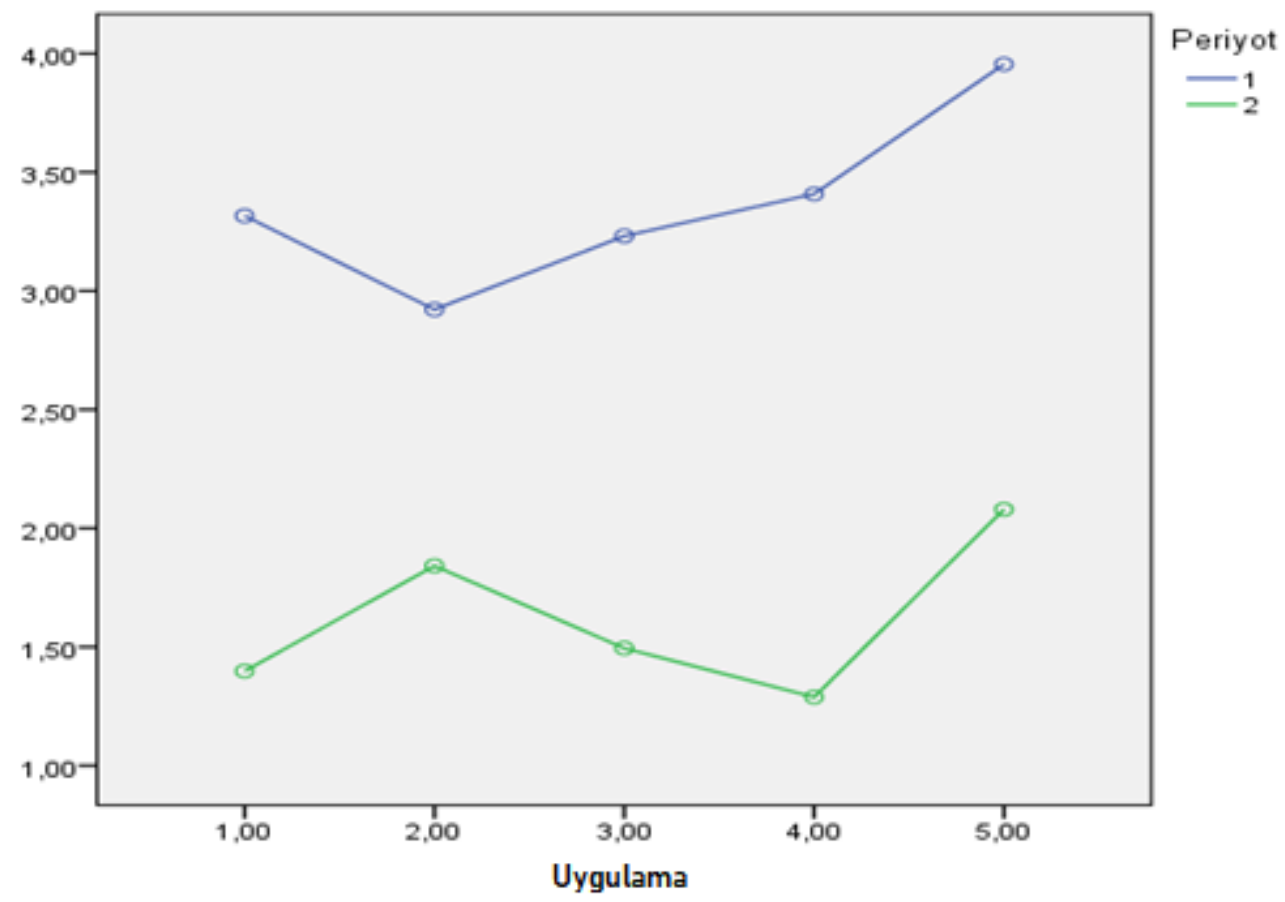

Şekil 9. Pestisit uygulanmış toprakların bakterivor nematod sayısı bakımından profil analizi. "Periyot 1: Uygulama öncesi, Periyot 2: Uygulama sonrası

"Uygulama 1: Satellite 20 WP, Uygulama 2: Status 330 E, Uygulama 3: Pesos 100 EC, Uygulama 4: Pentran 22 E, Uygulama 5: Kontrol

\subsection{Pestisit uygulamalarının toplam nematod sayısına etkisi}

Yapılan tekrarlanan ölçümlü varyans analizi sonucunda Periyot $\times$ Uygulama etkisi istatistiksel olarak önemli bulunmazken $(\mathrm{P}=0.380)$, hem periyot $(\mathrm{P}=0.000)$ hem de uygulamaların ana etkisi $(\mathrm{P}=0.009)$ istatistiksel olarak önemli bulunmuştur (Çizelge 8).

Çizelge 8. Pestisit uygulanmış toprakların toplam nematod sayısı bakımından tanıtıcı istatistikler

\begin{tabular}{lccc}
\hline \multicolumn{1}{c}{$\begin{array}{c}\text { Pestisit } \\
\text { Uygulamaları }\end{array}$} & $\mathrm{N}$ & Uygulama Öncesi & Uygulama Sonras1 \\
\cline { 3 - 4 } & & Ort. $\pm \mathrm{SH}$ & Ort. $\pm \mathrm{SH}$ \\
\hline Satellite 20 WP & 6 & $37.333 \pm 3.711 \mathrm{Ab}$ & $8.000 \pm 0.930 \mathrm{Bb}$ \\
Status 330 E & 6 & $40.833 \pm 2.135 \mathrm{Ab}$ & $11.166 \pm 2.482 \mathrm{Bb}$ \\
Pesos 100 EC & 6 & $48.333 \pm 4.514 \mathrm{Aa}$ & $9.666 \pm 1.115 \mathrm{Bb}$ \\
Pentran 22 E & 6 & $47.000 \pm 5.026 \mathrm{Aa}$ & $10.166 \pm 2.072 \mathrm{Bb}$ \\
Kontrol & 6 & $50.000 \pm 7.243 \mathrm{Aa}$ & $18.500 \pm 1.627 \mathrm{Ba}$ \\
Toplam & 30 & $44.700 \pm 4.906$ & $11.500 \pm 2.217$ \\
\hline
\end{tabular}

Not 1: Aynı satırda farklı büyük harflerle gösterilen ortalamalar arasındaki farklar önemlidir.

Not 2: Aynı sütunda farklı küçük harflerle gösterilen ortalamalar arasındaki farklar önemlidir.

Profil analizi sonuçları incelendiğinde hem uygulama öncesi ve sonrası, hem de kontrole (5. uygulama) göre tüm pestisit uygulamalarının toplam nematod sayısı üzerinde etkili olduğu bulunmuştur (Şekil 10). 


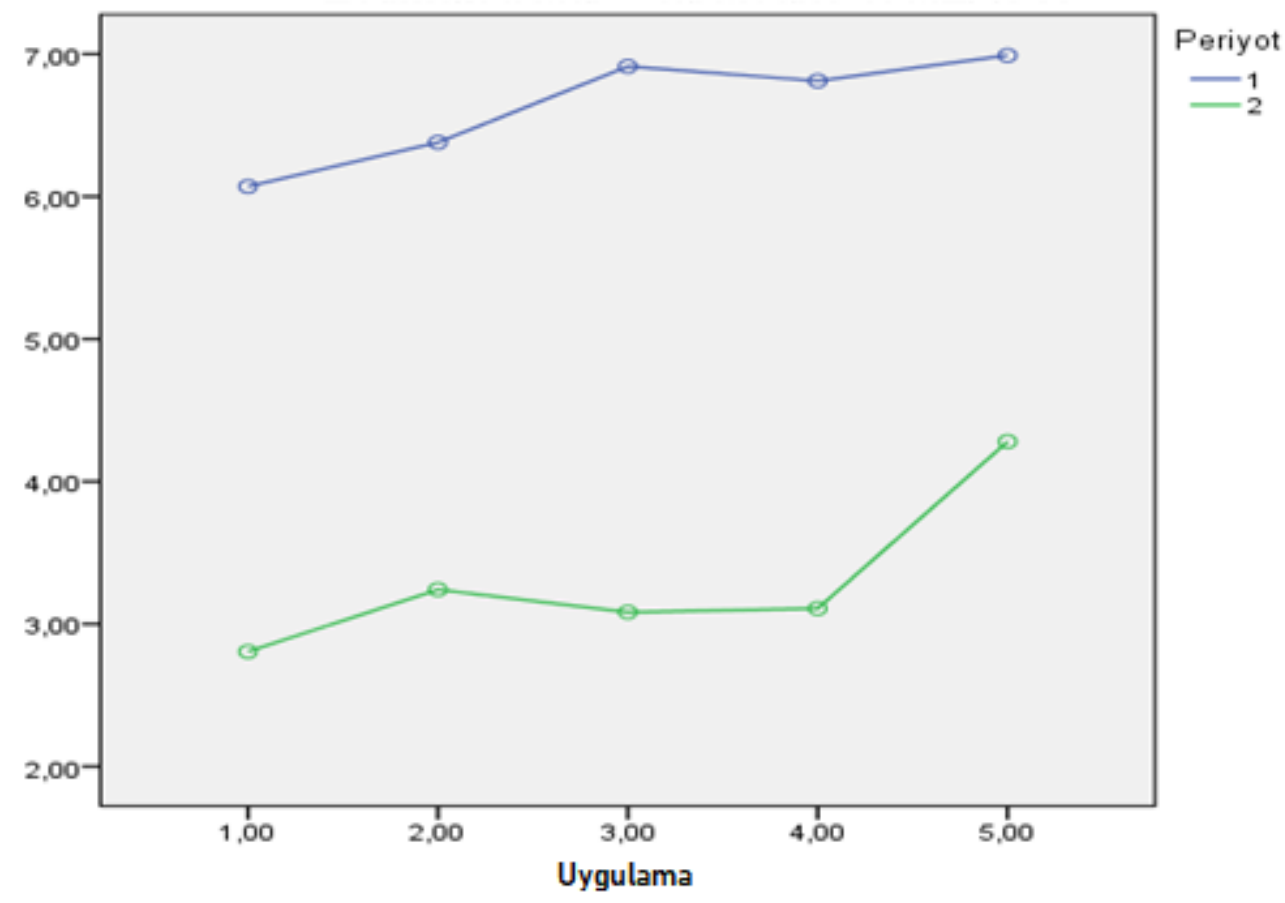

Şekil 10. Pestisit uygulanmış toprakların toplam nematod sayısı bakımından profil analizi.

*Periyot 1: Uygulama öncesi, Periyot 2: Uygulama sonras1

*Uygulama 1: Satellite 20 WP, Uygulama 2: Status 330 E, Uygulama 3: Pesos 100 EC, Uygulama 4: Pentran 22 E, Uygulama 5: Kontrol

\section{Tartışma ve Sonuc}

Tarımsal faaliyetlerde, zararlı ile mücadelede kullanılan kimyasal pestisitlerin olumlu ve olumsuz etkileri yıllardır tartışılmaktadır. Bitki koruma amaçlı bir pestisitten beklenen zararlıyı engellemesi ve başta insan olmak üzere diğer canlılara ve önemli parametreleri olumsuz etkilememesidir. Toprak pH's1 ile toprak canlılarından nematod, bakteri ve mikrofunguslar toprak sağ lığı açısından önemli parametrelerdir. Bu çalışmada, kontrole göre yapılan pestisit uygulamalarının toprak pH'sı üzerinde farklı etkide bulunduğu saptanmıştır. Elde edilen sonucun Arora ve ark. (2019)'nın ifadeleri ile paralellik gösterdiği, Koç ve Yardım (2019)'ın bulguları ile örtüşmediği tespit edilmiştir. $\mathrm{Bu}$ durumun denemelerin farklı ortamlarda (laboratuvar ve arazi) kurulması ve farklı pestisitleri kullanmalarından kaynaklanabileceği öngörülmektedir. Yapılan uygulamaların aerobik mezofilik bakterilere etkisi açısından profil analiz sonuçlarına göre kontrol ile kıyaslandığında tüm pestisitlerin toksik etki gösterdiği bulunmuştur. Bu bulguların Ubuoh ve ark. (2012), Al-Ani ve ark. (2019)'un bulguları ile tamamen Ören ve ark. (2009), Yousaf ve ark. (2013), Arora ve Sahni (2016) ile Wesley ve ark. (2017)'ın bulguları ile kısmen Koç ve Yardım (2019)'nın bulguları ile örtüşmediği görülmüştür. Ulaşılan bulguların örtüştüğü ve kısmen örtüştügü çalışmaların kontrollü laboratuvar şartlarında yapıldığı, örtüşmediği ya da kısmen örtüştüğü çalışmalarında ya arazi şartlarında yapıldığı ya da kullandıkları pestisit ve ölçüm farklılığı gibi durumlardan kaynaklandığı düşünülmektedir. Kontrol ile kıyaslandığında tüm pestisit uygulamalarının mikrofungus sayısı üzerinde etkide bulunduğu, Pesos 100 EC uygulamasında mikrofungus sayısında artışa sebep olmuşken diğer pestisitlerin toksik etki gösterdiği saptanmıştır. Ulaşılan bu sonuçların, Ören ve ark. (2009), Ubuoh ve ark. (2012), Arora ve Sahni (2016), Koç ve Yardım (2019) ile Al-Ani ve ark. (2019)'nın bulguları ile paralel Yousaf ve ark. (2013) ile Wesley ve ark. (2017)'nın bulguları ile kısmen örtüştüğü tespit edilmiştir. Gerek bakteri ve gerekse mikrofungus etkilenmesi durumunun; Lo (2010)'ın farklı pestisit yapılarının çeşitli toprak mikroorganizma gruplarının büyümesi üzerindeki ilişkilerinin kolayca tahmin edilemediği ve bazı pestisitlerin mikroorganizmaların büyümesini uyardığ 1 , ancak diğer pestisitlerin depresif etkilere sebep olduğu veya mikroorganizmalar üzerinde hiçbir etki göstermediği, Johns (2017)'ın toprakta yaşayan ve diğer bileşenlerle etkileşen organizmaların çoğalmasının, koşullara bağlı olarak büyük ölçüde değiştiğini ve bu durumların oldukça karmaşık ve dinamik olduğu şeklindeki görüşleri doğrultusunda 
olabileceği öngörülmektedir. Yapılan pestisit uygulamalarının, nematodlar üzerinde kullanılan pestisitin çeşidine göre az ya da çok etkili olduğu görülmüştür. Ulaşılan bu sonucun, Yardim ve Edwards (1998), Römbke vd. (2009) ve Koç (2017)'ın bulguları ile paralellik gösterdiği saptanmıştır. Sonuç olarak; yapılan uygulamaların toprak canlıları üzerinde genelde olumsuz olmak üzere etki gösterdiği tespit edilmiştir. Bu durumun, yukarıda verilen Lo (2010) ve Johns (2017)'ın ifadelerinin yanı sıra Arora ve Sahni (2016)'ın de çalışmasında, pestisitlerin, mikrobiyal aktiviteyi, toprak verimliliğini, toprak nematodları, solucanları ve protozoaları etkilediği şeklindeki bulguları ile örtüştüğü öngörülmektedir.

Gerek bu çalışmanın bulgularından ve gerekse benzer çalışmalardan hareketle;

1) Pestisitlerin tarımsal arazide kullanılmadan önce hedef canlı dışında mutlaka mikrodan makroya çoklu toksisite testlerinin yanı sıra toprak için hayati önem taşıyan fiziko-kimyasal parametrelere de bak1lmasi ve

2) Önerilen dozun aşılmaması ve en uygun şartlarda (iklim şartları ve zararlı durumu gibi) kullanılması gerektiği düşünülmekte ve önerilmektedir.

\section{Teşekkür}

Bu çalışmanın yürütülmesinde yardımcı olan Bitlis İl Tarım ve Orman Müdürlügüne, Prof. Dr. Mehmet MENDEŞ'e, Doç. Dr. Erdal SAKIN'e, Dr. Öğr. Üyesi Emre DEMİRER DURAK'a, Dr. Öğr. Üyesi Mehmet YILMAZ'a ve yüksek lisans öğrencisi Emrullah URGAN'a çok teşekkür ederiz.

\section{Kaynakça}

Al-Ani, M. A., Hmoshi, R. M., Kanaan, I. A., \& Thanoon, A. A. (2019). Effect of pesticides on soil microorganisms. In Journal of Physics: Conference Series (Vol. 1294, No. 7, p. 072007). IOP Publishing.

Anonim. (2019a). Türkiye cumhuriyeti çevre ve şehircilik bakanlığ1, https://cevreselgostergeler.csb.gov.tr/tarim-ilaci-pestisit-kullanimi-i-85834 Erişim tarihi: 2.10.2019.

Anonim. (2019b). Bitlis il tarım ve orman müdürlüğü. Bitlis ilinin tarımsal yapıs1. https://bitlis.tarimorman.gov.tr/Menu/18/Ilimizin-Tarimsal-Yapisi Erişim tarihi: 20.04.2019.

Arora, S., \& Sahni, D. (2016). Pesticides effect on soil microbial ecology and enzyme activity-An overview. Journal of Applied and Natural Science, 8(2), 1126-1132.

Arora, S., Arora, S., Sahni, D., Sehgal, M., Srivastava, D. S., \& Singh, A. (2019). Pesticides use and its effect on soil bacteria and fungal populations, microbial biomass carbon and enzymatic activity. Curr Sci, 116(4), 643-649.

Baermann, G. (1917). Eine einfache Methode zur Auffindung von Ancylostomum (Nematoden) Larven in Erdproben. Geneeskd Tijdschr Ned Indie, 57, 131-137.

Benson, H. J. (2001). Microbiological applications: A laboratory manual in general microbiology. Harold J. Benson. USA: The McGraw-Hill Companies. pp. 203.

Bouyoucos, G.J., (1951). A calibration of the hydrometer method for making mechanical analyses of soils. Agronomy Journal, 43, 434-438.

Craze, B. (1990). Soil survey standard test method soil moisture content. Department of Sustainable Natural Resources, 1-5.

Güven, A., Koç, İ. (2019). An overview of diseases, pests, weeds and commonly used pesticides in agricultural areas of Bitlis province, $1^{\text {st }}$ International Göbeklitepe Agriculture Congress. IGAC, Şanliurfa, Turkey.

Heinonen-Tanski, H., Simojoki, P., Raininko, K., Nuormala, N., \& Silvo, R. (1989). Effect of annual use of pesticides on soil microorganisms and sugar beet yields. Agricultural and Food Science, 61(1), 45-53.

Hussain, S., Siddique, T., Saleem, M., Arshad, M., \& Khalid, A. (2009). Impact of pesticides on soil microbial diversity, enzymes, and biochemical reactions. Advances in agronomy, 102, 159200.)

Jackson, M. L. (1958). Soil Chemical Analysis. PrenticeHall, Inc. Englewood Cliffs, New Jersey, USA, 498p.

Johns, C. (2017). Living soils: the role of microorganisms in soil health. Fut Direct Intl, 1-7. 
Koc, I. (2019). The Effect of Wood Vinegar Produced from Nutshells on the Soil Nematodes in Wheat Agro-Ecosystems. Fresenius Environmental Bulletin, 28: 3536-3544.

Koç, İ. (2017). Buğday agro-ekosistemlerinde pestisitlerin ve odun sirkesinin bazı etkilerinin tespiti üzerine bir araştırma, Yüzüncü Yıl Üniversitesi, Fen Bilimleri Enstitüsü, Doktora tezi, 253 sayfa, Van.

Koç, İ., \& Yardım, E, N. (2019). Pestisitlerin ve odun sirkesinin bazı mikrobiyal ve fiziko-kimyasal toprak parametrelerine etkilerinin araştırılması. Kahramanmaraş Sütçü İmam Üniversitesi Tarım ve Doğa Dergisi, 22(6), 896-904.

Küçük, Ç., Yeşilorman, D., \& Cevheri, C. (2016). Effect of Some Fungicides on Soil Biological Activities in Laboratory Conditions. Adlyaman Üniversitesi Fen Bilimleri Der., 6(2), 187-201.

Lo, C. C. (2010). Effect of pesticides on soil microbial community. Journal of Environmental Science and Health Part B, 45(5), 348-359.

Mendeş, M. (2012). Uygulamalı Bilimler için İstatistik ve Araştırma Yöntemleri. Kriter Yayınevi, İstanbul.

Mendeş M., Dincer E., \& Arslan E. (2007). "Profile analysis and growth curve for body mass index of broiler chickens reared under different feed restrictions in early age", Archiv Fur TierzuchtArchives of Animal Breeding, vol.4, pp.403-411.

Ören, A., Özbolat, K., \& Dığrak, M. (2009). Kahramanmaraş Yöresinde Yaygın Olarak Kullanılan Bazı Pestisitlerin Toprak Mikroorganizmaları Üzerine Etkisi. Kahramanmaraş Sütçü İmam Üniversitesi Doğa Bilimleri Dergisi 12(1), Kahramanmaraş.

Özbek, F. Ş., \& Fidan, H. (2014). Buğday üretiminde tarım ilaçları kullanımı: Konya ili örneği. Kahramanmaraş Sütçü İmam Üniversitesi Doğa Bilimleri Dergisi, 17 (3), 13-18.

Römbke, J., Schmelz, R. M., \& Knabe, S. (2009). Field studies for the assessment of pesticides with soil mesofauna, in particular enchytraeids, mites and nematodes: Design and first results. Soil Organisms, 81 (2), 237-264.

Southey, J. F. (1986). Extract of Meloidogyne Egg Masses. In: Southey JF (ed) Laboratory Methods for Work with Plants and Soil Nematodes. HMSO, London. 42-44 pp.

Ubuoh, E. A., Akhionbare, S. M. O., \& Akhionbare, W. N. (2012). Effects of pesticide application on soil microbial spectrum: case study-fecolart demonstration farm, Owerri-West, Imo state, Nigeria. International Journal of Multidisciplinary Sciences and Engineering, 3(2), 34-39.

Wesley, B., Ajugwo, G., Adeleye, S., Ibegbulem, C., \& Azuike, P. (2017). Effects of agrochemicals (insecticides) on microbial population in soil. EC Microbiology, 8, 211-221.)

Whitehead, A. G., \& Hemming, J. R. (1965). A comparison of some quantitative methods of extracting small vermiform nematodes from soil. Annuals of Applied Biology, 55, 25-38.

Yardim, E. N., \& Edwards, C. A. (1998). The effects of chemical pest, disease and weed management practices on the trophic structure of nematode populations in tomato agroecosystems. Applied Soil Ecology, 7 (2), 137-147.

Yeates, G. W. (1971). Feeding types and feeding groups in plant and soil nematodes. Pedobiologia, 8, 173-79.

Yeates, G. W., T Bongers., de Goede R. G. M., Freckman, D. W., \& Georgleva, S. S. (1993). Feeding habits in soil nematode families and genera - an outline for soil ecologists. Journal of Nematology, 25, 315-331.

Yıldız, Ş., Koç, İ., \& Yardım, E. N. (2017). Muş ilindeki bazı meraların nematod fauna yapısının incelenmesi. Yüzüncü Yıl Üniversitesi Tarım Bilimleri Dergisi, 27(2), 197-203.

Yousaf, S., Khan, S., \& Aslam, M. T. (2013). Effect of pesticides on the soil microbial activity. Pakistan Journal of Zoology, 45(4). 